UDC 323.26

\title{
M.V. Chernyshev
}

\section{TRADITIONAL ECONOMIES AND SOCIAL PROTEST IN WEST GERMANY AND ITALY IN 1966-1974}

Every crisis of the world capitalist economy prompts a new wave of interest in long economic cycles. In the second half of the $20^{\text {th }}$ century, the emergence of new social movements and activity of «traditional» working class can be analyzed as important barometers of socio-economic development in transitional economies of European countries towards postindustrial society. In this article the author employs a theory of the dynamics of protest waves developed by Ruud Koopmans to analyse social processes in West Germany and Italy between 1966 and 1974. Special attention is given to study of different types of social protest movements: spontaneous, semi-military groups and those affiliated with political parties. A special emphasis is put on showing how the protest wave started with confrontational actions, subsequently entered a phase of moderate mass mobilization, and ended up with a twin process of institutionalization and radicalization.

Keywords: capitalist economies, dynamics of protest waves, new social movements, Ruud Koopmans, Immanuel Wallerstein.

DOI: $10.35634 / 2587-9030-2019-3-4-475-482$

«But in order that these antagonisms and classes with conflicting economic interests might not consume themselves and society in a fruitless struggle, it became necessary to have a power seemingly standing above society that would alleviate the conflict and keep it within the bounds of 'order'. This power, arisen out of society but placing itself above it, and alienating more and more from it, is the state».

Engels, P. The Origin of the Family, Private Property, and the State. In R. C. Tucker (ed.) The Marx-Engels Reader. 2nd edition, London: Norton, 1977, pp. 177-178.

\section{Introduction}

In the 1980s, Immanuel Wallerstein created a concept of «phase T» to characterize a transition stage between the periods of prosperity and depression within the framework of the concept of long waves of capitalism. Analyzing the transitional period of 1966-1973, he characterized the events of 1968 as a «single revolution, which has a formative significance in the history of modern capitalist world-system» [1. P. 431]. His key argument was based on the idea that at that time protest events at the universities in different countries marked the beginning of important structural changes in Western capitalist economic system and introduced new forms of political participation including new anti-systemic collective identities in different countries: student, youth, women's, environmental movements developed. For Wallerstein (1990), to be anti-systemic means acceptance of the principle that «neither liberty nor equality is possible under the existing system and that both are possible only in a transformed world» [2. P. 45]. Herbert Kitschelt (1990) coined the term leftlibertarian to refer to appearance of the new type of parties: «They are left because they share with traditional socialism a mistrust of the market place, of private investment, and of the achievement ethic. They are libertarian because they reject the authority of the private or public bureaucracy to regulate individual and collective conduct» [3. P. 180]. This logic was supported by Wallerstein (1989) who highlighted an important point for the analysis of political and social events in 1968 that «the new movements were led largely by young people who had grown up in a world where the traditional anti-systemic movements emerged in the $19^{\text {th }}$ century in their countries were not in an early phase of mobilization but had already achieved their intermediate goal of state power» [4. P. 435].

Protest cycles are often affected by unpredictable events, and they almost never are under the control of a single movement organization. However, according to Tarrow (1989), social movements emerge when new opportunities are at hand - such as less repressive climate, splits within the elite, or in case of the presence of influential allies or supporters. He found that non-violent, confrontational actions like blockades and occupations peaked early in the wave. The high point of the wave is often marked by the appearance of supposedly spontaneous collective action, and more moderate, demonstrative actions peaked a few years later, and they increasingly involved established allies like trade unions [5. P. 70]. Subsequently, protests spread 
through the diffusion of tactical innovations developed by early protesters to other themes, groups, and locations. The tactical innovations that helped launch the second wave of protest partly consist of the extension of these forms of protest outside the student area and their adaptation to new goals [6. P. 642]. But this diffusion is not a spontaneous process. A competition between different protest groups «intensifies the evolution of the repertoire toward more radical forms, as movements try to show they are more daring than their opponents» [7. P. 54]. The conflicts that began in the mid-1960s continued with various campaigns into the 1970s and the 1980s but appeared in new and more organized forms.

\section{Key features of the "pre-revolutionary" period of the 1960s}

The period of 1950-60s witnessed the apogee of the European Keynesian state. This becomes easier to grasp when certain elements of economic statistics are taken into account. Between 1950 and 1973, government spending increased from 27.6 percent to 42 percent in West Germany, from 27.6 percent to 38.8 percent in France - at a time when the domestic product was itself growing faster than ever before or since [8. P. 361]. Each European country demonstrated steadily growing rates of per capita GDP and GNP - Gross Domestic Product and Gross National Product - "the newly sanctified measures of national strength and well being". Over the 1950s the average annual rate of GDP in West Germany was 6.5 percent, in Italy 5.3 percent, in France 3.5 percent. Overall, between 1950 and 1973, German GDP per head of the population more than tripled in real terms. The Italian economy, starting from a lower base, did even better [9. P. 325]. The claims of political analysts who give characteristics to this period are summarized with particular clarity in Tony Judt's study (2007) on postwar European history. Here, he outlines the following general propositions:

Doctrinal differences over the ostensible goals of the state might have noisily opposed Left and Right, Christian Democrats and Communists, Socialists and Conservatives, but almost everyone had something to gain from the opportunities the state afforded them for income and influence [...] The welfare state was avowedly social, but it was far from socialist. In that sense welfare capitalism, as it unfolded in Western Europe was truly post-ideological [10. P. 362].

Some peculiar characteristics were given to western capitalist economy of the 1960s by Alan Sorkin (1988). As he observed, the wholesale prices remained almost completely stable from 1961 through 1964 and then began to move upward slowly in 1965 as demand accelerated. Labor cost per unit of output remained relatively constant throughout the period from 1961 through 1966. This happened because wage increases generally did not exceed average gains in productivity. Major expenditures by industry on more efficient plants and equipment also helped keep labor costs stable. The unemployment rate did not fall below 5 percent of the labor force until late 1964, and unemployment was especially severe among teenagers throughout most of the 1960s [11. PP. 62-63].

Germany entered the 1960s as a full-employment economy exhibiting high international competitiveness due to low input prices and a modern capital stock. Throughout the decade, the economic growth remained well above the historical trend, although the economy grew less rapidly than in the 1950s. A major reason for lower growth in the 1960s was a reduction in the elasticity of labor supply. The indigenous labor force shrank because of the new generation entering the labor market was relatively small due to the low birth rates and the losses among the civilian population during and immediately after the war. The increasing scarcity of labor constrained economic growth in the early 1960s, even more so in the late years of the decade [12. P. 484]. In an attempt to alleviate the labor shortage, German firms began to recruit foreigners in larger numbers. Much of the investment in the national economy was therefore directly or indirectly exportinduced, and the growth continued to be export-led. This dependence was an important reason for the markedly more cyclical nature of the economic growth.

The investment activity rested in turn on longer-term profit expectations that were optimistic both among the public and the experts for the following reasons. The new economic order had proved to be efficient in bringing about high economic growth and full employment. By then, this economic situation was accepted by all major economic agents, and hence formed the basis for a strong social consensus. After full employment was achieved in the late 1950s, German trade unions used their enhanced bargaining power to successfully press for fewer annual working hours. At the same time, some negative factors were observed. The federal government was under continuous pressure from the business community to maintain the fixed parity. This fact produced a dilemma: given the high preference of Germans for price level stability, there 
Транзитные экономики и общественный протест в Германии и Италии...

was always the danger of imported inflation. An austerity policy was adopted, including restrictive monetary policy which leaded the country in 1966-67 to the first major postwar recession. Strong economic boom after that (between 1967 and 1970) was mainly based on high international price competitiveness of domestic suppliers due to the grossly undervalued currency. At the same time, productivity lagged somewhat behind production, and wage increases typically lagged about a year behind productivity increases. This wage lag in middle 1960s generated high profits in the first phase of the boom which induces firms to invest. Under the circumstances of economic boom German working class expected high profits, increased incomes and total economic stability. However, the inflation was higher than it had been in the 1950s, and was viewed negatively by analysts. Thus, by the end of the 1960s, the German economy had lost certain predictability of the earlier years. To a large extent this resulted from changes in public attitudes. Political and economic reconstruction had clearly come to an end and the idea gained currency that the time had come to enjoy the «fruits of the years of hard work» [13. P. 491].

The growth of the post-war Italian economy generated numerous and diverse interpretations which reflected the contradictions of the country development. First postwar governments in Italy based their plans for political and economic reconstruction on low wages and exclusion of the working class from the political power, with a consequent repression of the trade unions. The governments considered preserving public order as the primary task of the police [14. P. 68]. Nevertheless, by 1962 the national trade unions had sufficiently recovered their strength to obtain the first large-scale pay rises since the post-war period. The longstanding effect of this achievement was to diminish the effectiveness of one of the conditions which had made Italian enterprises competitive - low wages. Since that time the answer of Italian capitalism for the demands of transitional period was to increase productivity without increasing employment. As in the case of Germany, one of the causes bringing the economic miracle to the end was the fact that Italy had reached a situation of full employment (2.5 percent unemployment in 1963) [15. P. 49]. But this success was achieved due to the lowering of participation of the Italian citizens in labor force or because of the increase in emigration facilitated by the free market of labor established by the European Economic Community. The employment decreased in sectors employing marginalized and causal labor while it increased in the modern sectors which were better organized from the point of view of trade-union practitioners. In spite of government subsidies the crisis of 1964-1966 took its toll. Its consequences could be more serious but international demand was still strong to sustain Italian export. By 1969, when the short-lived recovery was coming to an end, deflationary government policies were difficult to implement. In order to achieve an annual increase of GDP of 5 percent while maintaining price stability the government tried to balance payment equilibrium and free trade. But this British technique of control of industrial relations could no longer work in Italy.

The very high level of industrial conflict which occurred by 1969 meant that the labor movement had become too strong to be defeated with seemingly traditional methods. The labor force was more homogenous than before as older skills became supplanted by new methods of production [16. P. 63]. By that time there were fewer women and workers over 45 involved in the production process. This younger, male working class expected to be among the beneficiaries of the economic miracle which came nearly to the end. At the end of the 1960s, Italy was passing through the complex process of social transformation. There was a very large decrease in the number of independent middle class and marginal proletariat. In the meanwhile, the proportion of white-collar workers increased significantly which signified the social trend toward postindustrial society. Certain general preconditions for the rise of the new feminist movement were formed: growing complexity of the women's role new role in production process, their marked subordination in the workplace, the impact of American feminism etc. But the most controversial problem seems to be the existence of youth issue. New entrants in the labor force found it more difficult to find a job. It looks like a paradox if one pays attention to the tendency toward full employment on the labor market. The rapid growth noticed during the period of economic miracle had come to an end around 1963 and yet education, particularly university education, expanded throughout the decade. Thus, the educational sector had become increasingly a parking area for unemployed young people. The main reason behind graduate unemployment was the fact that while education expanded the share of graduates taken up by the national industry began to fall after 1961. In that year the latter gave a possibility of employment to 16.9 percent of graduates. By 1964 this fell to 4.4 percent [17. P. 111]. Therefore, different social groups were ready to fight for their rights in the changed political circumstances. 


\section{Periods of social protest activity}

The period from 1967 to 1969 can be defined as a time of predominantly student movement. At the beginning of the 1960s, most protests in Germany were organized by two SMOs (social movement organizations) - the Socialist German Student League (SDS) and the peace movement Campaign for Disarmament. However, as it was emphasized by Koopmans (1993), the roles of these organizations declined sharply after 1967 [18. P. 649]. They had «cleared the ground» and protests began to diffuse much more spontaneously, often as a direct reaction to repressions from the government. The main roles in the protest scene were taken by rather different social actors such as youth organizations of SPD, liberal Free democratic party and unions but their capabilities of taking civic unrest under control were limited. The year of 1968 was signified by the highest proportion of unorganized spontaneous protests (56 percent) [19. P. 647]. Confrontational actions, however, declined sharply during the second half of the year.

In Italy the youth movement, emerged in the mid-1960s, was represented by members of national student unions and other self-governing student organizations within state universities. Groups with different ideological orientations took part in highly-organized UNURI, the student discussion club, which served as a reservoir of young leaders for political parties. In particular, a more radical wing emerged within the leftwing student-union UGI had strong ties with the Communist Party. But the most important fact is that the organizational resources for mobilization of new radical participants came especially from «workerist» groups and left journals [20. P. 86]. The ideology of these groups was called operaismo (workerism) because it stressed out predominant role of the working class and class conflicts. Toward the end of the 1960s plan committees began to regard contract agreements reached at the national level. This meant that industrial conflict extended beyond contract renewal periods and «the center of gravity» of strikes shifted from the national to local level. The number of national strikes expanded rather slowly throughout the period [21. P. 295]. «Hot autumn» of 1969, which stretched through the winter of 1970, was largely propelled by younger, unskilled mass workers, many of whom had southern parentage and lacked discipline. In Northern Italy, workers adopted forms of collective action previously used by the student movement in 1968. There were 302 million hours of strikes in 1969 and again 146 million in the following year [22. P. 62]. The reason for this type of social unrest quoted most frequently was a demand for quick establishment of assembly lines and intensification of the work process. This, as a result, had brought about worsening in working conditions, but sometimes it was caused by general dissatisfaction with the quality of life outside the factories. All of it contributed to politicization of working class demands. It is important to note that demands of the trade unions were not purely about wages: the most popular ones were associated with non-monetary issues such as quality of work process.

Taking into consideration economic factor, the possibilities of mobilization of new radical activists within the framework of old forms of protest in Italy were higher than anywhere in Europe. The high degree of connection between student, workers and Left parties made it possible to form a certain political strategy and appeal to the government after the first peaks of spontaneous protest. In spite of that, statistics shows that for a long period of time the two-thirds of the protests had involved well-known organizations, and half of them were organized by national trade-unions. By 1968, the proportion of protests associated with them dropped to less than half of the total, and only a quarter of them were interconnected with the unions. In the meanwhile, when the protest exploded, the police again used force to curb the protest: in 1968, three people were killed during marches organized by the trade unions, another three in 1969 [23. P. 29]. The shift in protest policing corresponded with a change in the party system. The crisis experienced by the Center-Left governments strengthened the position of hard-liners. The seeds of institutionalization and radicalization of New Social Movements were planted by the growing involvement of professional SMOs and external allies on one hand, and the increasing repression coming from confrontational political actors (neofascist movement and conservative governments) on the other.

\section{The Revolutionary front}

The period of 1970-73 can be called the «Revolutionary front». It is characterized by the decline of mobilization within the universities and the growth of protest beyond the academic world. A few new issues, in particular, regarding urban problems and gender discrimination, were raised. The main political tendency in West Germany at this time was a significant electoral success of moderate left parties. The SPD made large electoral gains and even became the largest party in the elections of 1972. Moreover, hundreds of thou- 
Транзитные экономики и общественный протест в Германии и Италии...

sands of new members penetrated into the ranks of the party, particularly its youth organization, the Jusos [24. P. 644]. Similarly, in Italy the Communist Party enlisted several hundred thousand new members. The left-libertarian movements - under the hegemony of the New Leftist discourse - used symbols and frames of reference that were known and accepted by the PCI. At least until 1970, the larger part of the left-libertarian movements perceived the Old Left, and in particular the PCI, as their main ally and supported it [25. P. 28]. Starting from that time the trend of social activity began to reverse in both factories and universities. It was caused by two main factors: the trade unions managed to integrate many of the young workers into their structures, and second, the student movement was increasingly absorbed by far-leftist organizations that had emerged from mass movement of 1968. After the collective action was brought back within the organizational political framework, the rates of social unrest started decreasing. It could be explained by the fact that in the early 1970s the state used violence against the radicalized left-wing movements that, on several occasions, reverted to the most brutal traditions of the 1950s. Public opinion was polarized, and the quantitative data show that after 1971 more spontaneous violence, widespread at the beginning of the cycle, tended to be substituted by semi-military forms of violence. The percentage of violent cases was higher than the average of the entire period in both countries.

\section{Downfall of the protest}

The period from 1974 to 1977 can be characterized as a time of decline of civic resistance in both countries. Particularly in the factories, the international economic crisis of the early 1970s put pressure on activists and the latter had to concentrate on the defense of what had been gained in the previous years. One indicator of the crisis experienced by the protest movements in this period was that in the 1976 national election the parties of the New Left won only a few hundred thousand votes. As mass mobilization declined, particularly in the factories, relations between the New Left organizers and the trade unionists deteriorated. After the Constitutional Court in Germany rejected the new law on abortion in 1975, the women's movement in this country abandoned its more political themes and proclaimed a «retreat» into private life. Mass mobilization in support of the legalization of abortion in Italy lasted until 1976. After the decline of the student movement, the attempt was repeated by some New Left organizations, but once again the hope to mobilize the working class remained unfulfilled. The semi-military structure of these groups was particularly appealing to younger militants, socialized into politics in the 1970s. The number of forms of violence adopted by small groups increased - a series of terrorist attacks by the Rote Armee Fraction were executed in which several dozens of people were killed.

Small groupings of the New Left in Italy radicalized their ideology and strategy too, preparing the ground for the development of the autonomous type of violence. This phase ended with the first premeditated murder carried out by the Red Brigades, as other groups also began to appear beyond accepted legal norms. The analysis of the frequency of social protest in the last period shows that between 1969 and 1973 only 8 percent of acts involved violence against people, whereas between 1974 and 1977, 50 percent were directed against people [26. P. 652]. Confronted with strong and violent radical Right and radicalized New Left, more conservative political forces demanded a policy of law and order to curb «the opposite extremists». The relations between protestors and the police only got worse. Although the government of national unity signaled for depolarization in the party system, social movement activists claimed continuation of resistance against the authoritarian state.

\section{How to mobilize thousands: two kinds of social discourse related to the protests}

Although the role of the governments and different social actors in the mass protest during 1966-1974 in Italy and Germany remains debatable, the main socio-economic factors which determined the social unrest were: decreased rates of economic growth and wage lag in Germany, low wages and youth unemployment in Italy. The tendency of slowdown of economic growth in the 1960s was mainly associated with the gradual decline of capital input and labor productivity. This malaise was mainly conditioned by changes in the economic environment that took place between the late 1960s and mid-1970s. But as Rossi (1996) argued, the economic problems of Italy had largely non-economic causes. Most of them can ultimately be traced back to less than satisfactory adjustment of Italian society to the economic reality created by largely unanticipated rapid growth [27. P. 443]. The resulting combination of low growth, relatively high inflation but stable employment among traditional working class can be seen as the price which the society had to pay for the rein- 
forced multidimensional struggle over the distribution of country income - capital versus labor, young versus middle aged, women versus men's social supremacy etc. In both countries the social unrest began with the student demonstrations against administrative decisions of authorities, although they lasted longer in Italy and declined rapidly in Germany. The logic of social protest was framed in two kinds of social discourse: an anti-authoritarian and class-conflict discourses. The first one was particularly strong at the beginning of the protest wave (occupation of the universities, public meetings) and expressed generational problems of the youth. Later on it conflicted with the more traditional discourse of class conflict.

The logic of development of social protest in Italy had little to do with only student activism - strong ties between students and workers were close and frequent. In contrast to this, in Germany one could notice very occasional alliances between the working class and the left-libertarian movements. Anti-authoritarian slogans were especially popular there. In the words of Thomas (2003), «conflicts over the meaning of democracy were at the heart of the 1960s protests in Germany and these battles were, for all sides, informed by a constant awareness of the catastrophic consequences that had resulted from the failure of democracy in the past» [28. P. 239]. The waves of protest related to changes in configuration of the two main political parties in both countries (Social Democrats and Christian Democrats) and their position toward use of police in suppressing protest groups.

Factors that explain the origins and growth of the phenomenon of social protest may not necessarily explain its continuance. Comparing the two countries, the policing of the protest in Italy was much «harder» - that is, over the decade several forms of protest were repressed with the use of force. In comparison with the single periods, it was observable particularly in the early 1970s; for the 1960s, instead, more visible break with the previous «hard» style of protest policing can be detected. I suppose that protest policing implemented in certain states does not depend only on the right-left characteristic of governments, although the comparative analysis of policy in West Germany and Italy shows that conservative governments were more inclined to use more repressive policy than the coalition governments (the Center-left in Italy and Grand party coalitions in West Germany). Moreover, Della Porta (1995) argued that «in Germany, the adoption of a neocorporatist model of industrial relations in the immediate postwar period induced, probably more than any other factor, a relatively tolerant state attitude toward the opposite social movements» [29. P. 73]. The fact that class conflict in Italy was not institutionalized in rigid terms explains both the formation of large system alliances between the Old Left and new social movements and harsh repression they encountered from the state in the first half of 1970s.

When the protest movements first appeared, the institutional actors denied their legitimacy and treated them as antidemocratic or criminal. In the short term, polarization of the political spectrum followed; in the long run, new forms of collective action have become part of the postindustrial society. At the beginning of the transitional period of 1966-1974 there was a significant change in behavior of trade unions and national governments. First of all, labor shortage in the 1960s substantially strengthened the bargaining power of the unions. In Western Germany, as a lagged response to the tight labor market, the unions successfully pressed the government for wage increases and more income distribution that exceeded the increases in labor productivity by a large margin. The cost of labor was further increased by new labor legislation. This included, among other things, continued wage payments in case of illness (for six weeks), employers' contributions to employees' health insurance. To paralyze counteracting forces from abroad, trade unions acted in favor of immigration ban for foreign labor (enacted in 1974) and later, supported by the business, for protection of labor-intensive industries.

In Italy one can see particularly curious consequences of the labor protest activity. Increases in wages before 1969 were matched by increases in productivity. After 1969, wages increased at a rate higher than the cost of living and exceeded the productivity rates. Inflation rates in the 1960s were in line with the rest of the OECD countries, but after 1973-74 the former were, on average, twice bigger [30. P. 66]. The latter regulation of labor market both in Italy and Western Germany made labor tend to become a fixed and hence induced the reduction of jobs in the course of natural fluctuation - via capital-labor rationalization. As a result, there was a massive increase in public expenditures relative to the national product and a shift from public investment to consumption took place. The consequences of the social protest activity in the two countries had a reverse side: the substantial growth in wages, money transfers, and state regulations coincided with the need for high financial flexibility and adaptability due to massive pressure to the transitional economies. Here is the evidence: economic growth and social stability were higher when the wage policies in both states were moderate and income distribution shifted in favor of capital. They suffered decline after the phase of 
Транзитные экономики и общественный протест в Германии и Италии...

aggressive wage policies that pushed up the wage share in gross national product; soon thereafter in the late 1970 s, real wages increased slowly and mass unemployment emerged.

The initial strategy of repression imposed by the governments during the peak of protests failed, and in the second phase the authorities combined the continuing repression of certain protest organizations with efforts to appease other parts of protest movement. Thus, the radical and moderate wings of the latter continued to grow, but became increasingly distinguishable. Moderate groups were integrated into the political system and gradually abandoned protest activities, while the representatives of anti-systemic movements were not satisfied with the gains that had been made, and decisions about continuation of protest activities became their exclusive domain. The result of radicalization of the last group was spiraling violence and counterviolence by the governments, which contributed to formation of terrorist organizations in the later period. Last but not least, integration and radicalization lead to a decline in spontaneous social protests - moderate movements were no longer interested in protest activities as their attention shifted to conventional channels of political participation, while extremist violence advocated by radicals became too costly for most participants of social movements to take part in.

\section{REFERENCES}

1. Wallerstein, I. Zukin, S. 1968, Revolution in the World-System: Theses and Queries. Theory and Society Vol. 18, no. 4, 1989, pp. 431-449.

2. Wallerstein, I. Antisystemic Movements: History and dilemmas. In Amin, S., Arrighi, G., Frank, A.G. and I.Wallerstein (eds.) Transformating the Revolution. New York: Monthly Review, 1990, pp. 13-53.

3. Kitschelt, H. New Social Movements and the Decline of Party Organization. In Dalton, R. and Kuechler, M (eds.) Challenging the Political Order: New Social and political Movements in Western Democracies. New York: Oxford University Press: 1990, pp. 179-208.

4. Wallerstein, I. Zukin, S. 1968, Revolution in the World-System: Theses and Queries. Theory and Society Vol. 18, no. 4,1989 , pp. 431-449.

5. Tarrow, S. Democracy and Disorder: Protest and Politics In Italy, 1965-1975. Oxford: Oxford University Press, 1989.

6. Koopmans, R. The Dynamics Of Protest Waves: West Germany, 1965 to 1989. American Sociological Review, Vol. 58, 1993, pp. 637-658.

7. Tarrow, S. Democracy and Disorder: Protest and Politics in Italy, 1965-1975. Oxford: Oxford University Press, 1989.

8. Judt, T. Postwar: A History of Europe since 1945. London: Pimlico, 2007.

9. Judt, T. Postwar: A History of Europe since 1945. London: Pimlico, 2007.

10. Judt, T. Postwar: A History of Europe since 1945. London: Pimlico, 2007.

11. Sorkin, A.L. Monetary and Fiscal Policy and Business Cycles in the Modern Era. Lexington, Massachusetts/Toronto: Lexington Books, 1988.

12. Hennings, K.H. Germany: Country Experience. In Boltho, A. (ed.) The European Economy. New York: Oxford University Press, 1982, pp.472-501.

13. Hennings, K.H. Germany: Country Experience. In Boltho, A. (ed.) The European Economy. New York: Oxford University Press, 1982, pp.472-501.

14. Sasson, D. Contemporary Italy: Politics, Economy and Society since 1945. London, New York: Longman, 1986.

15. Sasson, D. Contemporary Italy: Politics, Economy and Society since 1945. London, New York: Longman, 1986.

16. Sasson, D. Contemporary Italy: Politics, Economy and Society since 1945. London, New York: Longman, 1986.

17. Sasson, D. Contemporary Italy: Politics, Economy and Society since 1945. London, New York: Longman, 1986.

18. Koopmans, R. The Dynamics of Protest Waves: West Germany, 1965 to 1989. American Sociological Review, Vol. 58, 1993, pp. 637-658.

19. Koopmans, R. The Dynamics of Protest Waves: West Germany, 1965 to 1989. American Sociological Review, Vol. 58, 1993, pp. 637-658.

20. Della Porta, D. Social Movements, Political Violence, and the State: a Comparative Analysis of Italy and Germany. Cambridge University Press, 1995.

21. Tarrow, S. Cycles of Collective Action: Between Moments of Madness and the Repertoire of Contention. Social Science History, Vol. 17, no. 2, 1993, pp. 281-307.

22. Sasson, D. Contemporary Italy: Politics, Economy and Society since 1945. London, New York: Longman, 1986.

23. Della Porta, D. Social Movements, Political Violence, and the State: a Comparative Analysis of Italy and Germany. Cambridge University Press, 1995.

24. Koopmans, R. The Dynamics of Protest Waves: West Germany, 1965 to 1989. American Sociological Review, Vol. 58,1993 , pp. 637-658. 
25. Della Porta, D. Social Movements, Political Violence, and the State: a Comparative Analysis of Italy and Germany. Cambridge University Press, 1995.

26. Koopmans, R. The Dynamics of Protest Waves: West Germany, 1965 to 1989. American Sociological Review, Vol. 58, 1993, pp. 637-658.

27. Rossi, N., and Toniolo, G. Italy. In Crafts, N. and Toniolo, G (eds.) Economic Growth in Europe since 1945. Cambridge University Press, 1996, pp. 427-453.

28. Thomas, N. Protest Movements in 1960s West Germany: a Social History of Dissent and Democracy. Oxford, New York: Berg, 2003.

29. Della Porta, D. Social Movements, Political Violence, and the State: a Comparative Analysis of Italy and Germany. Cambridge University Press, 1995.

30. Sasson, D. Contemporary Italy: Politics, Economy and Society since 1945. London, New York: Longman, 1986.

Received 02.09.2019

Chernyshev Maxim V., PhD candidate

University of Siena, Department of Political and International sciences

Via Pier Andrea Mattioli, 10 - Siena

E-mail: maxim_chernyshev@yahoo.com

\section{М.В. Чернышев \\ ТРАДИЦИОННЫЕ ЭКОНОМИКИ И ОБЩЕСТВЕННЫЙ ПРОТЕСТ В ГЕРМАНИИ И ИТАЛИИ В 1966-1974 гг.}

DOI: $10.35634 / 2587-9030-2019-3-4-475-482$

Каждый кризис в рамках мировой капиталистической системы вызывает новую волну интереса к длинным экономическим циклам. Появление во второй половине 20 века новых общественных движений и активность «традиционного» рабочего класса можно рассматривать в качестве важных индикаторов социально-экономического развития в переходных экономиках европейских стран, двигавшихся в направлении постиндустриального общества. В данной статье автор предпринимает попытку применить теорию динамики волн общественного протеста (Рууд Купманс) к анализу процессов, имевших место в Западной Германии и Италии в период 1966-1974 гг. Особое внимание уделяется изучению разных типов движений общественного протеста: спонтанных, полувоенных и связанных с политическими партиями. Подчеркивается, что волна общественного протеста начинается с конфронтационных действий, затем переходит в фазу умеренной общественной мобилизации и заканчивается параллельно идущими процессами институционализации и радикализации.

Ключевые слова: капиталистическая экономика, теория динамики волн протеста, новые общественные движения, Рууд Купманс, Иммануил Валлерстайн.

Чернышев Максим Владимирович, $\mathrm{PhD}$ кандидат Университет Сиены

Via Pier Andrea Mattioli, 10, Сиена, Италия

E-mail: maxim_chernyshev@yahoo.com 